\title{
Suspendable macromolecules are responsible for ice nucleation activity of birch and conifer pollen
}

\author{
B. G. Pummer ${ }^{1}$, H. Bauer ${ }^{2}$, J. Bernardi ${ }^{3}$, S. Bleicher ${ }^{4}$, and H. Grothe ${ }^{1}$ \\ ${ }^{1}$ Institute of Material Chemistry, Vienna University of Technology, Austria \\ ${ }^{2}$ Institute of Chemical Technologies and Analytics, Vienna University of Technology, Austria \\ ${ }^{3}$ USTEM, Vienna University of Technology, Austria \\ ${ }^{4}$ Atmospheric Chemistry Research Laboratory, University of Bayreuth, Germany
}

Correspondence to: H. Grothe (grothe@tuwien.ac.at)

Received: 20 September 2011 - Published in Atmos. Chem. Phys. Discuss.: 5 October 2011

Revised: 27 February 2012 - Accepted: 28 February 2012 - Published: 7 March 2012

\begin{abstract}
The ice nucleation of bioaerosols (bacteria, pollen, spores, etc.) is a topic of growing interest, since their impact on ice cloud formation and thus on radiative forcing, an important parameter in global climate, is not yet fully understood. Here we show that pollen of different species strongly differ in their ice nucleation behaviour. The average freezing temperatures in laboratory experiments range from 240 to $255 \mathrm{~K}$. As the most efficient nuclei (silver birch, Scots pine and common juniper pollen) have a distribution area up to the Northern timberline, their ice nucleation activity might be a cryoprotective mechanism. Far more intriguingly, it has turned out that water, which has been in contact with pollen and then been separated from the bodies, nucleates as good as the pollen grains themselves. The ice nuclei have to be easily-suspendable macromolecules located on the pollen. Once extracted, they can be distributed further through the atmosphere than the heavy pollen grains and so presumably augment the impact of pollen on ice cloud formation even in the upper troposphere. Our experiments lead to the conclusion that pollen ice nuclei, in contrast to bacterial and fungal ice nucleating proteins, are non-proteinaceous compounds.
\end{abstract}

\section{Introduction}

As the phase transition from liquid to frozen water at temperatures below $273 \mathrm{~K}$ is kinetically hindered, droplets of ultrapure water can remain liquid down to temperatures of $235 \mathrm{~K}$. Only structures, which ease the cluster formation in the water, can cause freezing at temperatures as high as the thermodynamic freezing point. These particles are called ice nuclei
(IN). In most cases ice nucleation is not caused by the total IN surface, but only by definite active sites. Atmospheric IN can trigger cloud glaciations and precipitation, having an impact on both the global radiation balance and the water cycle. The impact on the balance is still debated, as on the one hand ice clouds have a higher albedo than liquid water, so they should cool the climate (Mishchenko et al., 1996), but on the other they are more likely to precipitate and so reduce total cloud albedo (Lohmann, 2002).

Atmospheric IN can be of non-biological or biological origin. Among the latter are the ice-nucleating proteins discovered in some bacterial and fungal species, like Pseudomonas syringae (Schnell and Vali, 1972; Wolber et al., 1986), Fusarium avenaceum (Pouleur et al., 1992), and Rhizoplaca chrysoleuca (Kieft and Ruscetti, 1990). Some biogenic ice nuclei, however, are non-protein compounds (Gross et al., 1988; Mugnano et al., 1996).

Biological particles comprised about a third of all ice crystal residues (Pratt et al., 2009) for an air mass sampled in the western United States. For ice nucleation measurements in the Amazon basin, biological particles were found to account for a significant fraction of the ice nucleation-active particles, particularly at temperatures warmer than $\sim 248 \mathrm{~K}$ (Prenni et al., 2009). However, significant uncertainties remain in the understanding of the ice nucleation efficiencies of various biological particles (Möhler et al., 2007; DeMott and Prenni, 2010). Further, it is likely that the relative importance of biological ice nuclei varies on regional and seasonal scales similar to that observed for biological aerosol (Burrows et al., 2009; DeMott and Prenni, 2010). 
Pollen were identified and studied as efficient cloud condensation nuclei (Dingle, 1966; Pope, 2010), but only few species were studied in all four primary ice nucleation modes (Diehl et al., 2001, 2002; von Blohn et al., 2005). While pollen were IN inactive in the deposition freezing mode, they nucleated in condensation, immersion and contact modes. The measured median freezing temperatures were in the range from 252 to $261 \mathrm{~K}$ for immersion freezing. However, no research has been carried out to analyze the nature of pollen IN, although it has been suspected that pollen IN activity can be derived from their rough, porous surface structure, since pollen are known to have nano-sized pores in their exine (Kovacik et al., 2009). The exine is the outer wall of the pollen, consisting of a robust, very inert biopolymer called sporopollenin, which is composed of aromatic and aliphatic hydrocarbons.

\section{Methods: nucleation measurements}

Fifteen different pollen species were investigated: silver birch (Betula pendula), common hazel (Corylus avellana), goat willow (Salix caprea), plane tree (Platanus orientalis), ragweed (Ambrosia artemisiifolia), wormwood (Artemisia absinthium), redtop (Agrostis gigantea), corn (Zea mays), Scots pine (Pinus sylvestris), Irish yew (Taxus baccata), common juniper (Juniperus communis), Pfitzer juniper (Juniperus chinensis pfitzeriana), Northern whitecedar (Thuja occidentalis), Chinese arborvitae (Thuja orientalis) and stinging nettle (Urtica dioica). To distinguish between the juniper species, the common juniper is referred to as "juniper I", the Pfitzer juniper as "juniper II", the Northern whitecedar as "thuja I" and the Chinese arborvitae as "thuja II". This way a broad spectrum of different samples from all over the seed plant taxon has been covered: pine, yew, thuja and juniper belong to the conifer phylum. Birch, hazel, willow and plane tree are typical broadleaf trees, which are dicotyledons (they have two seed leafs after germination). Redtop and corn are, like all the grasses, monocotyledons (they have one seed leaf after germination), while ragweed, wormwood and nettle are dicotyl herbs.

The juniper II pollen were collected in the tree nursery of Kagran in Vienna. The other conifer pollen as well as nettle and wormwood pollen were purchased from Pharmallerga ${ }^{\circledR}$, and all other pollen from Allergon $A B{ }^{\circledR}$. As a reference, Snomax ${ }^{\circledR}$ was chosen which consists of shreddered Pseudomonas syringae cultures carrying an IN active protein complex which nucleates at temperatures about $270 \mathrm{~K}$. Due to its high IN efficiency it is commercially available as an additive for snowguns.

Measurements were performed with cryo-microscopy: the core of the experimental setup was a cryo cell consisting of a three-stage Peltier element of the type UEPT-330-119$045 \mathrm{C} 200$, which is placed in a Teflon box and cooled with water of $290 \mathrm{~K}$ (see Fig. 3). The device was constructed at the Institute of Material Chemistry at the Vienna University of Technology. In the cap of the Teflon box a glass window allows inspection of the cell inside. The cryo cell was placed on a light microscope desk with the glass window below the objective. The microscopes used were a Zeiss Axio ScopeA1 and an Olympus BX51, and photos were taken with a MDC200 microscope camera. While and after opening the cell, e.g. when changing the sample, it had to be flushed with nitrogen or synthetic air to keep out air humidity, which would disturb the measurements.

The Peltier element can be cooled to temperatures below $220 \mathrm{~K}$ with a measurement error smaller than $\pm 1 \mathrm{~K}$. The accuracy of the temperature measurement was checked by observing the melting process of pure water droplets, which is supposed to take place at $273 \mathrm{~K}$ at a pressure of $1 \mathrm{~atm}$.

The samples were measured in oil immersion mode, where small water droplets were dispersed in an oil matrix (Marcolli et al., 2007). The sample pollen were suspended in the emulsion and distributed between the two phases. The emulsion consisted of $45 \mathrm{wt} \% \mathrm{MilliQ}^{\circledR}$ water and $55 \mathrm{wt} \%$ oil, which itself was composed of $90 \mathrm{wt} \%$ paraffin and $10 \mathrm{wt} \%$ lanolin (water-free grade). About $50 \mathrm{mg}$ pollen per $\mathrm{ml}$ water were added, as this concentration led to the highest amount of droplets containing exactly 1 or 2 pollen grains. The prepared samples were placed on a glass slide and set onto the Peltier stage, where they were chilled with a cooling rate of 1-2 $\mathrm{K} \mathrm{min}^{-1}$. Frozen droplets appear dark due to increased light scattering and contain visible internal structures, like edges or cubes. Finally, the fraction of frozen droplets was plotted against the current temperature. Only droplets with diameters of 10-200 $\mu \mathrm{m}$ were accounted for, because smaller droplets are more difficult to observe, and larger droplets do not appear beyond the lower troposphere. Moreover, larger droplets demand more space, so fewer droplets could be observed in the display window of the microscope camera during one nucleation experiment, what would limit the statistical power.

The different samples were compared by a characteristic number, the median freezing temperature, which is the temperature with $50 \%$ of all droplets frozen. This value is more reliable than the initial freezing temperature, which is the temperature where the first droplet freezes, because the latter one may be manipulated by outliers and is less reproducible. The different median freezing temperatures of pollen species are shown in Fig. 1 and Table 1. To compare our results with mineral dust we additionally carried out measurements with two dusts applied in nucleation measurements with concentrations of $2.4 \mathrm{wt} \%$, namely Arizona Test Dust (ATD) and kaolin, which is a common and active mineral ice nucleus (Zimmermann et al., 2008).

Additionally, nucleation rates were determined by measuring birch and pure water isothermally at different temperatures. Therefore the frozen fraction is plotted versus the measurement time (see Fig. 5 and Table 3). 


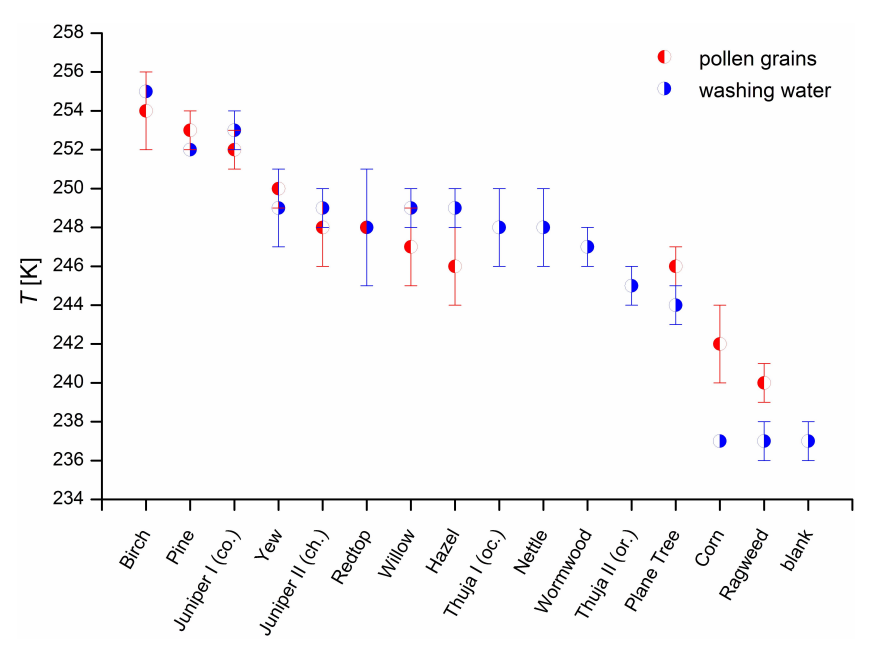

Fig. 1. Median freezing temperatures of different pollen samples: whole pollen grains and washing waters. The error bars mark the standard deviation rounded to integer numbers in Kelvin. If the calculated error is smaller than $0.5 \mathrm{~K}$, no error bars are given.

In order to check if we could reproduce our results in an experimental setup closer to reality, we carried out measurements at the simulation chamber at BayCEER, University of Bayreuth (Pummer et al., 2011). To prevent the pollen from sedimenting quickly, they were shreddered with a swing mill of the type Retsch MM400. Considering the methodological differences, as well as small systematic errors of the chamber measurements, the determined median freezing temperatures were in the same range for one sample in both setups. Due to uncertainties of a few Kelvin, and as they were not the main intention of this study, the chamber results are not applicable for more profound discussion. Consequently the accomplishment of future experiments with freely floating droplets for comparison will be of importance.

\section{Results and discussion}

\subsection{Pollen surface topology}

In the past the ice nucleation activity of pollen has been explained by the general roughness and porosity of the pollen surface (Diehl et al., 2001), thus generating possibly active sites for ice nucleation. Measurements with scanning electron microscopy (FEI Quanta ${ }^{\mathrm{TM}} 200$ FEGSEM) have shown that all pollen have a rich surface topology (see Fig. 4). Although pollen from different species exhibit differences on the microscale, their different ice nucleation activities cannot be directly correlated with their microtexture, respectively microstructural elements. Even species with a similar microtexture, resulting from close relatedness, can show different nucleation behaviour. For example, birch and hazel are in the same family and their pollen look similar, but their median freezing temperatures differ by 6 to $8 \mathrm{~K}$ (see Fig. 4 and
Table 1. Median freezing temperatures from the oil immersion mode and the flow tube measurements: $T_{50}$ stands for the temperatures, where $50 \%$ of all droplets are frozen (median freezing temperatures), with A for the whole pollen grains in oil immersion, $\mathrm{B}$ for the washing waters in oil immersion and $\mathrm{C}$ for immersion freezing measurements by Diehl et al. (2002).

\begin{tabular}{lccccc}
\hline $\begin{array}{l}\text { sample } \\
{[\mu \mathrm{m}]^{1}}\end{array}$ & $\begin{array}{c}d \\
{[\mathrm{~K}]^{2}}\end{array}$ & $\begin{array}{c}T_{50}^{\mathrm{A}} \\
{[\mathrm{K}]^{2}}\end{array}$ & $\begin{array}{c}T_{50}^{\mathrm{B}} \\
\text { pos }^{3}\end{array}$ & $\begin{array}{c}\% \\
{[\mathrm{~K}]^{4}}\end{array}$ & $T_{50}^{\mathrm{C}}$ \\
\hline Snomax & - & - & 268 & 100 & - \\
Birch & 20 & 254 & 255 & 100 & 259 \\
Pine & 40 & 253 & 252 & 70 & 257 \\
Juniper I & 20 & 252 & 253 & 100 & - \\
Yew & 20 & 250 & 249 & 68 & - \\
Juniper II & 20 & 248 & 249 & 100 & - \\
Redtop & 20 & 248 & 248 & 58 & - \\
Willow & 20 & 247 & 249 & 34 & - \\
Hazel & 25 & 246 & 249 & 77 & - \\
Thuja I & 20 & - & 248 & 48 & - \\
Nettle & 13 & - & 248 & 62 & - \\
Wormwood & 20 & - & 247 & 63 & - \\
Thuja II & 20 & - & 245 & 38 & - \\
Plane Tree & 20 & 246 & 244 & 74 & - \\
Corn & 65 & 242 & 237 & 100 & - \\
Ragweed & 20 & 240 & 237 & 100 & - \\
blank & - & - & 237 & 0 & $<243$ \\
ATD & - & 252 & - & - & - \\
Kaolin & - & 250 & - & - & - \\
\hline & & & & &
\end{tabular}

1 average pollen grain diameters according to SEM measurements

2 droplet sizes: $10-200 \mu \mathrm{m}$

3 percentage of droplets that froze heterogeneously in the immersion measurements with washing waters

4 droplet sizes: $256-373 \mu \mathrm{m}$

Table 1). The same statements apply to the thuja and the juniper species, which all belong to one family.

\subsection{Chemical analysis}

We showed that water, which was in contact with pollen for some hours, adopted the ice nucleation activity and keeps it after separation from the pollen grains (see Fig. 1 and Table 1). Therefore pollen and water were mixed and left for some hours at room temperature, being occasionally shaken up again. Then the water fraction was decanted or, if the pollen did not sediment well, filtrated. The applied pollen concentration for preparing the washing water was $50 \mathrm{mg} \mathrm{ml}^{-1}$. Both the washing water and the washed pollen bodies showed the same IN activity in cryomicroscopic measurements as the untreated pollen. Nucleation data showed two steps for most species: one at approximately the same temperature as the whole pollen grains, and another at the homogeneous nucleation temperature at $237 \mathrm{~K}$ (see Fig. 2). The most important concept that emerges from these data is the fact that the active sites of the pollen are suspendable nano-structures on the pollen, which are too small 


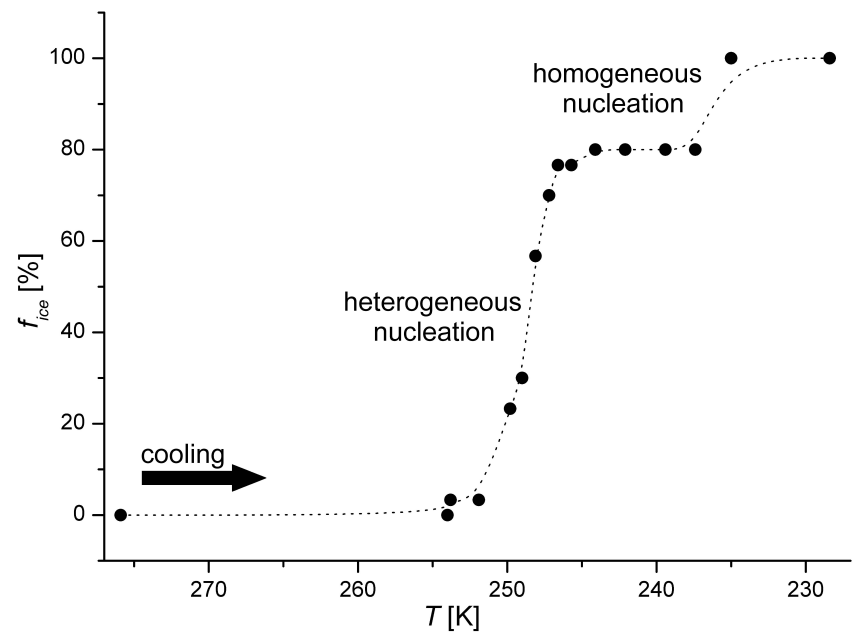

Fig. 2. The curve shows a typical nucleation curve (temperature vs. number fraction of frozen droplets $f_{\text {ice }}[\%]$ ) for an oil emulsion with washing water of hazel pollen. Some droplets nucleate at about $237 \mathrm{~K}$, meaning that they do not contain IN. For the determination of the median freezing point only the heterogeneous nucleation step is used. The fraction that nucleates heterogeneously in the washing water experiments is given for each species in Table 1.

to be recognized in the electron microscope, but easily leave the pollen bulk. Furthermore, the relative amount of IN on the pollen can be correlated with the ratio of the two steps in the nucleation curve. While the birch sample was fully frozen $(100 \%)$ before reaching the homogeneous nucleation temperature, others show far lower heterogeneous nucleation behaviour (see Table 1). This finding could be explained by the fact that the IN on some pollen are scarce or inefficient. This is most likely the reason for the broad steps in the nucleation spectra of some species, as individual pollen show individually different ice nucleation behaviour, if the IN concentration on the pollen varies on a low level. For example, willow and hazel pollen grains showed a large freezing temperature span, a discrepancy of some Kelvin between whole pollen grain and washing water nucleation, and a high fraction of homogeneous nucleation events.

By drying the washing water we were able to show that the upper threshold for residue content in the water is about $2.4 \mathrm{wt} \%$. Consequently we chose concentrations of $2.4 \mathrm{wt} \%$ for our reference samples (Snomax ${ }^{\circledR}$, ATD, kaolinite) in order to make them comparable with our pollen data.

The hypothesis of macromolecular IN could be verified by analyzing the residue with transmission electron microscopy (TEM, FEI Tecnai F20). Therefore a droplet of washing water was placed on a carbon-coated copper grid and left to dry up. After that the residues were investigated. These residues lack structures down to the level of about $10 \mathrm{~nm}$, so the IN cannot be much bigger than that. To estimate the mass range of the IN, washing water was filtered with Vivaspin ${ }^{\circledR}$ tubes of different mass exclusion limits. Vivaspin ${ }^{\circledR}$ tubes are com-
Table 2. Median freezing temperature dependence (in K) on thermal, chemical and enzymatic treatment.

\begin{tabular}{lcccccc}
\hline treatment & Snomax & Birch & Pine & Juniper & blank \\
\hline none & 268 & 255 & 252 & 253 & 237 \\
\hline $355 \mathrm{~K}^{1}$ & & 262 & 254 & - & 249 & - \\
$385 \mathrm{~K}$ & & 263 & 254 & 251 & 249 & - \\
$415 \mathrm{~K}$ & & 235 & 250 & 249 & 246 & - \\
$445 \mathrm{~K}$ & & 236 & 247 & 241 & 237 & - \\
$460 \mathrm{~K}$ & & - & 236 & 236 & 234 & - \\
$475 \mathrm{~K}$ & & - & 236 & - & - & - \\
\hline Pronase & & 263 & 255 & 251 & 252 & 237 \\
Papain & & - & 254 & 249 & 249 & 237 \\
Lipase & & - & 253 & 250 & 253 & 238 \\
Amylase & & - & 255 & 251 & 253 & 235 \\
Cellulase & & 265 & - & 251 & 251 & 237 \\
\hline \multirow{4}{*}{$\mathrm{H}_{2} \mathrm{SO}_{4}$} & $0.5 \mathrm{M}$ & - & 252 & 244 & 248 & 232 \\
& $5.0 \mathrm{M}$ & - & 240 & 234 & 236 & 232 \\
\hline \multirow{2}{*}{$\mathrm{G}^{2} \mathrm{Cl}^{2}$} & $10.0 \mathrm{M}$ & - & 231 & - & - & 232 \\
\hline
\end{tabular}

${ }^{1}$ the temperature to which the sample is heated before nucleation measurements

${ }^{2} \mathrm{G} \cdot \mathrm{Cl}$ stands for guanidinium chloride

mercially available plastic tubes horizontally separated into two compartments by a polyethersulfone membrane. The upper compartment is filled with the solvent to filtrate. When the tube is centrifuged at $4000 \mathrm{rpm}$, the solvent is pressed through the membrane. Only molecules below a given mass may pass the membrane, while larger molecules are retained. This way the solvent is free of molecules larger than the mass limit of the membrane. Vivaspin ${ }^{\circledR}$ tubes can be purchased with different upper mass limits: we applied tubes with 5, 10, $30,50,100$ and $300 \mathrm{kDa}$. Only filtrates of the $300 \mathrm{kDa}$ tubes kept their IN activity, while all others became IN-negative leading to the conclusion that the pollen IN have a mass of 100 to $300 \mathrm{kDa}$.

To characterize and identify pollen IN, some stress tests were performed with the washing waters of selected pollen species: birch, pine, yew, juniper I, willow, hazel. For testing the thermal stability, which, together with other data can assist the determination of the chemical nature of the IN, each sample was heated to the demanded temperature (preparations have been performed in a range from 355 to $460 \mathrm{~K}$ ) for $1 \mathrm{~h}$. Then the water-free residue was re-suspended in water again and used for oil immersion measurements. The species differed in their thermal stability, with a stability range up to $445 \mathrm{~K}$ for birch and pine (see Table 2).

Our measurements indicate further that pollen IN are nonproteinaceous compounds, as they were insensitive to treatment with $6 \mathrm{M}$ guanindinium chloride, which was added to washing water and destroys the structure of proteins (Breslow and Rizzo, 1991). As the Snomax ${ }^{\circledR}$ IN is a protein, it 


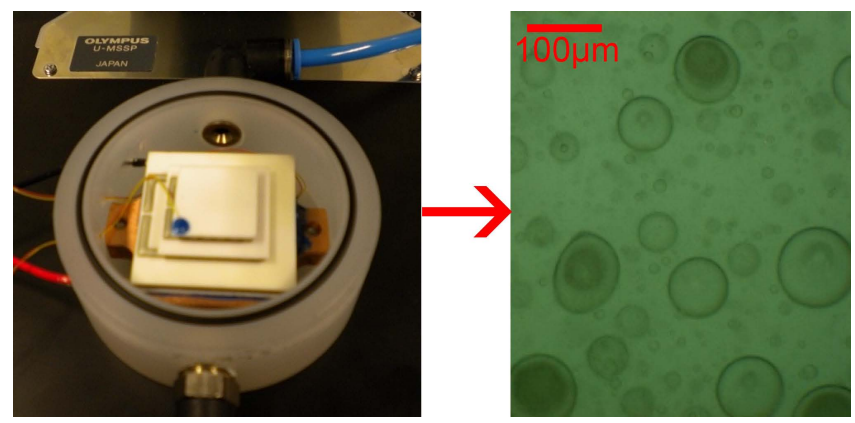

Fig. 3. The cryo cell used for oil immersion measurements, and a partly frozen pure water emulsion photographed at $237 \mathrm{~K}$.

was affected by treatment with guanidinium chloride in our study. A reduction of the nucleation temperature for some Kelvin can be explained by the increase of electrolyte concentration, which appears also at the pure water reference (see Table 2). The nuclei were also insensitive to proteinbreakdown by the enzymes pronase $\mathrm{E}$ and papain. Therefore $5 \mathrm{mg} \mathrm{ml}^{-1}$ pronase $\mathrm{E}$ was added to the washing water, which was then stored for $4.5 \mathrm{~h}$ at $310 \mathrm{~K}$. The same procedure was carried out with $2 \mathrm{mg} \mathrm{ml}^{-1}$ papain and incubation for $5 \mathrm{~h}$ at 340 K. Papain treatment was not applied on $\operatorname{Snomax}^{\circledR}$, as it already decomposes thermally at the demanded temperature optimum. As the $\mathrm{pH}$ of the applied $\mathrm{MilliQ}^{\circledR}$ water was about 6 , no $\mathrm{pH}$ adjustment, which could manipulate nucleation temperatures, was necessary. This procedure was also performed with pure MilliQ ${ }^{\circledR}$ water to prove that the procedure itself has no influence on the nucleation temperature. Snomax ${ }^{\circledR}$ was applied as a second reference, which is knowingly vulnerable to enzymatic treatment, to prove that the methods are applicable. The same procedure was carried out with pancreas lipase, which breaks down fats: washing water was spiked with $2 \mathrm{mg} \mathrm{ml}^{-1}$ lipase and then heated to $308 \mathrm{~K}$ for $3 \mathrm{~h}$. Again the IN kept their activity. Digestion with $5 \mathrm{mg} \mathrm{ml}^{-1}$ cellulase Onozuka (breaks down cellulose) for $4.5 \mathrm{~h}$ at $310 \mathrm{~K}$ and with alpha-amylase (breaks down many, but not all alpha-glycosidic sugar bonds) for $3 \mathrm{~h}$ at $313 \mathrm{~K}$ showed no effect on nucleation temperatures either (see Table 2).

As in agreement with literature, the denaturation of the bacterial ice nucleating protein with a protease or by moderate heat did not totally eliminate ice nucleation, but decreased temperatures for about $5 \mathrm{~K}$. This is consistent with measurements of IN proteins in the past (Kieft and Ruscetti, 1990; Tsumuki and Konno, 1994). Only under severe stress (e.g. temperatures above $400 \mathrm{~K}$ or treatment with guanidinium chloride) Snomax ${ }^{\circledR}$ fully lost its ice nucleation activity. To test the stability in acidic conditions, pollen were incubated at different sulphuric acid concentrations $(0.5 \mathrm{M}$, $5 \mathrm{M}, 10 \mathrm{M})$ and different temperatures $(293 \mathrm{~K}, 333 \mathrm{~K}, 358 \mathrm{~K})$ for $1 \mathrm{~h}$. After that, all samples were diluted to a concentra-

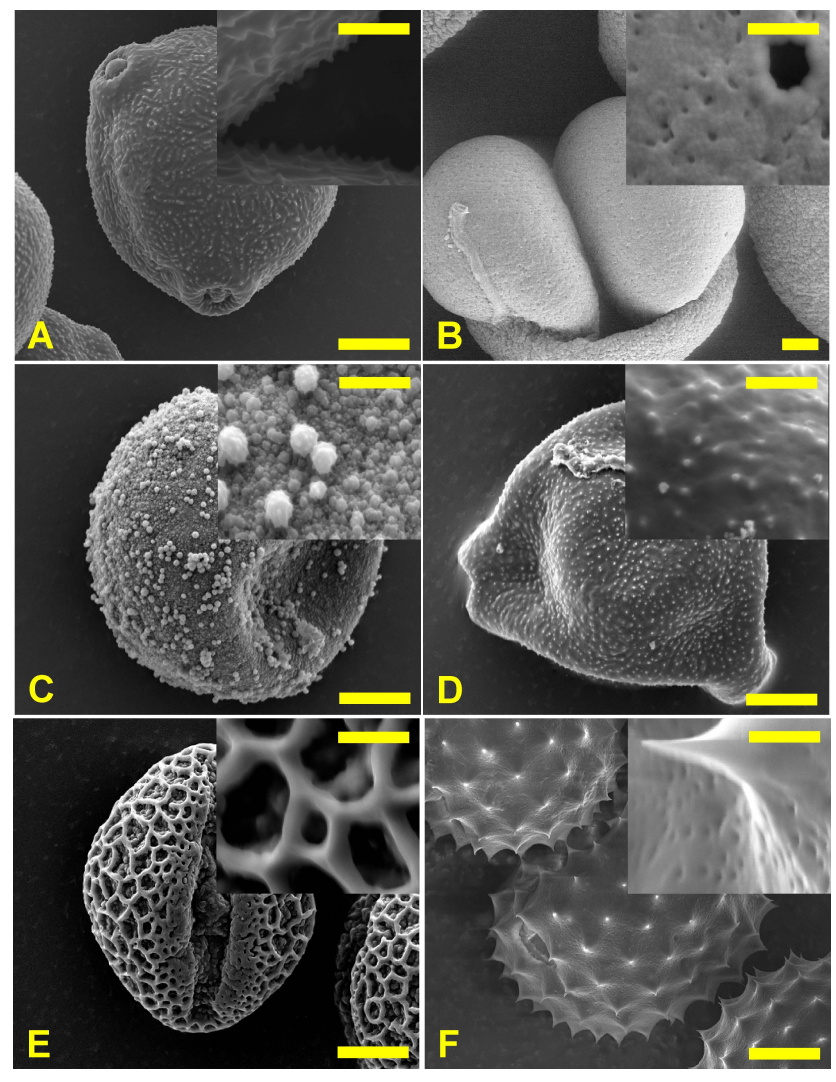

Fig. 4. SEM images of birch (A), pine (B), juniper I (C), hazel (D), willow (E) and ragweed (F). The bar length is $5 \mu \mathrm{m}$ in the large and $1 \mu \mathrm{m}$ in the small images.

tion of $0.5 \mathrm{M}$ sulphuric acid, otherwise the nucleation point decreases too much, simply due to the high presence of an electrolyte. At least $5 \mathrm{M}$ sulphuric acid was required to destroy the IN. As a side effect, the sample turns dark orange, which might be the result of sample oxidation. With $10 \mathrm{M}$ sulphuric acid the sample turned immediately red, and when heating it blackened due to carbonization.

In order to separate the colligative freezing point depression caused by the presence of an electrolyte from the effect of IN denaturation in the experiments with guanidinium chloride and sulphuric acid, model calculations were carried out by T. Koop, University of Bielefeld (Zobrist et al., 2008; Koop and Zobrist, 2009). These calculations showed, that the freezing point depression caused by $1 \mathrm{M}$ guanidinium chloride or $0.5 \mathrm{M}$ sulphuric acid is about 2 to $3 \mathrm{~K}$. The experimental values for $T_{50}$ of pollen in guanidinium chloride are less than $2 \mathrm{~K}$ lower than calculated, so the IN were not damaged. The value for Snomax ${ }^{\circledR}$, however, was $5 \mathrm{~K}$ lower than predicted, implicating a slight denaturation effect. For the $6 \mathrm{M}$ guanidinium chloride nearly the same $T_{50}$ values were measured for the pollen, while the blank $T_{50}$ value decreased further. We think this is caused by the fact that the simple addition of a colligative effect (freezing-point depression) and 
a non-colligative effect (ice nucleation) becomes less precise for higher electrolyte concentrations. Calculations for pollen treated with $0.5 \mathrm{M}$ sulphuric acid show that for birch, as well as for the blank, the measured $T_{50}$ values lie only 1 to $2 \mathrm{~K}$ below the calculated values. For pine the discrepancy is $6 \mathrm{~K}$, which can only be explained by a slight denaturation of the pollen IN. Full denaturation, however, occurs only at $5.0 \mathrm{M}$ sulphuric acid. In the case of juniper I, where the $T_{50}$ value is $3 \mathrm{~K}$ lower than predicted for pure freezing point depression, we cannot say for sure, if it is caused by a purely colligative, or additionally a small denaturation effect.

\section{Conclusions}

\subsection{Nucleation rates}

Strictly speaking freezing is a time-dependent statistical process, so in fact the definition of the median freezing temperature may be questionable. Therefore we carried out isothermal nucleation measurements (see Sect. 2). By correlating the fraction of frozen particles with the measuring time, one can calculate nucleation rates by the equation (Murray et al., 2010):

$\ln \left(\frac{n_{\mathrm{tot}}-n_{\mathrm{nuc}}}{n_{\mathrm{tot}}}\right)=-J \cdot V \cdot t$

where $n_{\text {tot }}$ is the total droplet number, $n_{\text {nuc }}$ the number of frozen droplets, $t$ the time in seconds, $V$ the average droplet volume in $\mathrm{cm}^{3}$ and $J$ the nucleation rate in $\mathrm{cm}^{-3} \mathrm{~s}^{-1}$. Formally the droplet freezing is treated as a first-order decay reaction with liquid droplets as reagent and $J$ as reaction rate constant.

The nucleation rate measurements are isothermal. With increasing time more and more droplets freeze. But measurements in this study, as well as others (Murray et al., 2010), confirm that $J$ strongly depends on the temperature, so that laboratory measurements can only be performed in a temperature interval of few Kelvin (see Fig. 5 and Table 3). Due to this steep slope median freezing is reached either within milliseconds some degrees below, or within years some degrees above this interval. For this reason it is legitimate to concentrate on this narrow window with nucleation rates of about $10^{5} \mathrm{~cm}^{-3} \mathrm{~s}^{-1}$ and define the corresponding temperature as the median freezing temperature. As a consequence, nucleation spectra can be constructed, where the fraction of frozen particles is plotted against $T$ without any time dependence. According to this approximation, the principally stochastic freezing event is considered to be singular (Niedermeier et al., 2011).

In this study, the homogeneous nucleation rate $J_{\text {hom }}$ was determined with MilliQ ${ }^{\circledR}$ water droplets in the temperature range from 236.5 to $240.5 \mathrm{~K}$. Emulsions with birch washing water were measured to calculate the heterogeneous nucleation rate $J_{\text {het }}$ for this sample at 254 to $258 \mathrm{~K}$ (Table 3).

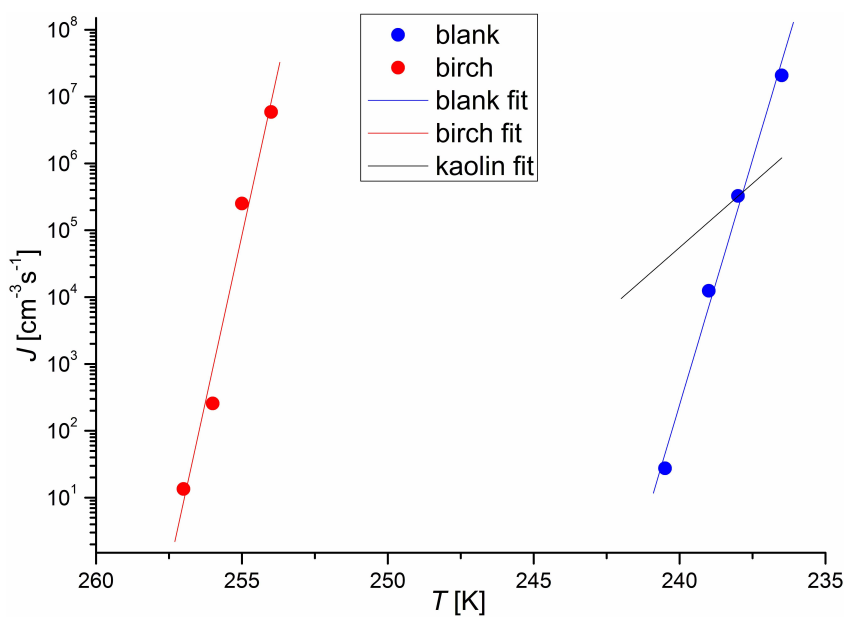

Fig. 5. Plot of the nucleation rates $J_{\text {hom }}^{\text {blank }}$ and $J_{\text {het }}^{\text {birch }}$ (Table 3 ). The kaolin fit was taken from Murray et al. (2011), and converted into comparable units by multiplication with $0.7162 \mathrm{~cm}^{-1}$, which is the ratio of maximum particle surface per droplet and the average droplet volume.

Concerning nucleation rate calculations, it has to be admitted that the suggested volume dependence is only exact for homogeneous freezing, while for heterogeneous freezing it is determined by the amount of IN per droplet (Iannone et al., 2011). However, if the IN are homogeneously distributed in the aqueous phase, larger droplets should contain a higher number of IN, leading to a pseudo-dependence on the droplet size. As a consequence, droplets of similar size behave more or less the same way, but if the droplets differ much in size (e.g. more than one order of magnitude), the size dependence becomes more impressive.

Nucleation rates in the sense of Eq. (1) are superior to median freezing temperatures, as they account for the droplet size (which is an approximate and relative measure for IN numbers per droplet). Median freezing temperatures are difficult to compare between studies, as they do not contain information about droplet size, concentration or the measurement setup. They are ideal for a plain comparison of different samples within one measurement series, but they should not be seen as absolute values. Currently nucleation rates are the most advanced tool to compare the efficiency of ice nuclei. To make studies more comparable one could define two standard reference points, e.g. the median freezing temperatures of Snomax ${ }^{\circledR}$ and of pure water, relative to which all other data should be compared.

\subsection{Remarks about methods}

As pollen are not produced under sterile laboratory conditions like microorganisms, the question arises, if pollen IN activity might be caused by bacteria growing on the material, as it is the case on decaying leaf litter (Vali et al., 1976). But the different biochemical and thermal properties make this 
Table 3. Listing of nucleation rates $J\left[\mathrm{~cm}^{-3} \mathrm{~s}^{-1}\right]$ at given temperatures for pure water droplets and droplets containing birch pollen. The results are plotted in Fig. 5.

\begin{tabular}{ccc}
\hline$T[\mathrm{~K}]$ & blank & birch \\
\hline 236.5 & $2.07 \times 10^{7}$ & \\
238.0 & $3.27 \times 10^{5}$ & \\
239.0 & $1.24 \times 10^{4}$ & \\
240.5 & $2.75 \times 10^{1}$ & \\
254.0 & & $5.89 \times 10^{6}$ \\
255.0 & & $2.53 \times 10^{5}$ \\
256.0 & & $2.57 \times 10^{2}$ \\
257.0 & & $1.35 \times 10^{1}$ \\
\hline
\end{tabular}

hypothesis very unlikely (see Sect. 3.2), so we are convinced that the IN have to originate from the pollen itself.

Although the median freezing temperatures of measurements by Diehl et al. (2002) differ for some Kelvin from the data of this study, they are principally within the same range. Differences can be explained by following deviations from our oil immersion measurements: (i) the individual differences between different biological samples, (ii) the droplets in the oil immersion are static, while the droplets in a wind channel are dynamic and can collide, causing local pressure fluctuations that enhance the number of ice-like clusters leading to crystallization (Cheftel et al., 2006), (iii) the larger droplet diameter of 256 to $373 \mu \mathrm{m}$ increases the concentration of IN per droplet at a given concentration, and so the IN activity, (iv) a slight change in the surface tension of the droplets caused by the oil matrix might change nucleation temperatures. All these considerations together might explain the small difference between nucleation temperatures.

\subsection{Interpretation and impacts}

Overall, we have shown that the ice nucleating activity of pollen can be derived from macromolecules, which cause different ice nucleation behaviour of different pollen species. Although these IN have not been fully characterized yet, several substance classes can be excluded. For example, the structure of proteins is destroyed by $6 \mathrm{M}$ guanidinium chloride, as we have shown with the ice nucleating protein in Snomax ${ }^{\circledR}$ (see Sect. 3.2). Our pollen ice nuclei, however, were not affected at all. The IN could be polysaccharides, which are common substances on the pollen surface (Clarke et al., 1979; Grote, 1989) and have already shown IN activity in past studies (Goldstein and Nobel, 1991; Goldstein and Nobel, 1994). This hypothesis is consistent with the behaviour in sulphuric acid, as the cooking of food samples in concentrated sulphuric acid is a standard method to break down and measure the carbohydrate content (Dubois et al., 1956). Biological saccharides can be either free or bound to proteins to form so-called glycoproteins. If the pollen ice nuclei are the latter, then their activity has to be caused by the sugar side chains alone and not the protein core. Alternatively, the IN might be oxidized organic polymers.

The heat degradation curve of Snomax ${ }^{\circledR}$ (see Table 2) shows two steps which could be explained by different levels of destruction: biomolecules have several levels of structuring. The primary structure, which is the sequence of monomers, is the most stable structure, but is by far not enough for biomolecules to fulfil their purpose. The tertiary structure is the general arrangement of the protein and is the most fragile. In general, for a full-working biomolecule all structures have to be intact - the more the structures are damaged the lower is the biological activity. A loss of the tertiary structure alone can totally or partly deactivate the function of a biomolecule. As a consequence, we believe that the steps in the heat degradation curve of Snomax ${ }^{\circledR}$ resulted from the stepwise reduction of structure and therefore of nucleation activity, while the most robust pollen samples (birch, pine) kept their IN activity up to about $400 \mathrm{~K}$ and do not fully lose their activity at temperatures up to about $450 \mathrm{~K}$. This higher thermal stability points at polysaccharides rather than at the usually more sensitive proteins.

In the past, pollen have been rejected as important atmospheric IN, as they are not as abundant in the atmosphere as bacteria or mineral dust and are too heavy to reach higher altitudes. According to recent model calculations (Hoose et al., 2010) average pollen concentrations are below $100 \mathrm{~m}^{-3}$ above the continental surface and nearly zero above the oceanic surface. Another study (Jacobson and Streets, 2009) estimates global pollen emissions to be nearly twice as high. Locally and temporarily (e.g. in a forest during pollen season) pollen can reach concentrations of thousands $\mathrm{m}^{-3}$ and cause intensive particle scattering of sunlight, which leads to the so-called pollen corona (Mims, 1998). Even the annual global emission is not constant, as there are so-called mast-years, in which pollen concentrations in the atmosphere can be much higher than average (Kelly, 1994). Pollen concentrations strongly decrease with altitude, so that there are nearly no pollen at $5 \mathrm{~km}$ height. However, as we showed in this study, the pollen body is not required to cause ice nucleation, but just some macromolecules, which can be separated very easily from the pollen, and can principally reach higher altitudes. It is known that material from the pollen, such as allergens and sugars, can indeed leave the pollen body and be distributed independently. The most probable mechanism is the pollen grain bursting by rain, which releases material, such as allergens (Schäppi et al., 1999). As a consequence allergenic material was found in aerosol particles smaller than $5 \mu \mathrm{m}$, which contained no pollen or larger fragments (Solomon et al., 1983). The release of material by bursting of wet pollen has been observed by electron microscopy (Swoboda et al., 2001). Not only allergens, but also sugars originating from pollen can be detected in the atmosphere (Yttri et al., 2007). These authors see pollen rupture 
and wood burning as their main sources in the atmosphere. The contrast between the hydrophilic properties of many of the surface components and the relative hydrophobia of the sporopollenin boosts the suspension of surface components in water droplets. According to that we conclude that the impact of pollen on the global atmosphere might have been underestimated.

It is interesting to note that pollen from species inhabiting higher geographic latitudes showed high nucleation activity. The best ice nuclei - birch, pine and juniper I pollen - are from plants indigenous to regions as far as the Northern timberline, and birch is additionally one of the first blooming species in the year, namely from February to April. On the other hand, the least active ice nuclei, thuja II, plane tree, corn and ragweed, are late bloomers (May or even later) and originated from regions of lower geographic latitudes. As it has been proven for other organisms that extracellular freezing is a protection mechanism developed by evolution in order to enhance the chance of survival in cold environments (Duman, 2001; Howe et al., 2003), the pollen IN could be indeed a cryoprotective adaptation, which prevents frost injury by controlling the freezing process (Zachariassen and Kristiansen, 2000). Another approach suggests that ice nucleation, as it eases precipitation, helps atmospheric microorganisms to return to the ground and so colonize new habitats (Morris et al., 2004). This mechanism might also suit anemophilous plant species, as their pollen have to sediment after distribution by wind in order to pollinate female florescence. However, it might be the case that an appreciable fraction of the pollen grains might be destroyed in the process due to grain bursting.

As a whole, our results support the hypothesis that some pollen are more potent ice nuclei than fresh soot and dust (von Blohn et al., 2005). Although the mass concentrations of $2.4 \mathrm{wt} \%$ in the washing water in our study seem to be high, it has to be considered that this was the upper threshold for total extractable material. As there are many different substances on the pollen surface, and most of them are inactive or even have antifreeze activities (e.g. low-molecular sugars and salts), the concentration of active sites has to be far lower, most likely vanishing low compared to the non-active material. Nucleation measurements with oil immersions of ATD (Marcolli et al., 2007) show that the maximum nucleation intensity occurs at temperatures of 246 to $250 \mathrm{~K}$ depending on the particle size for concentrations of $2.5 \mathrm{wt} \%$. $T_{50}$ of birch measured in this study was $254 \mathrm{~K}$, while ATD nucleated at $252 \mathrm{~K}$. Fresh soot shows median freezing temperatures below $247 \mathrm{~K}$ for droplet sizes in the range of $170-410 \mu \mathrm{m}$ (Diehl and Mitra, 1998). Other publications are difficult to compare (an overview is given by Ariya et al., 2009), as some of them lack essential information, such as IN concentrations. Another problem are the large droplet radii, causing a huge number of IN per droplet, even if concentrations are low. Our measurements with kaolin and ATD show that the IN of the most active pollen species show higher median freezing tem- peratures at (most likely) far lower concentrations. Certainly pollen ice nuclei cannot reach the very high IN activity of INpositive bacteria and fungi, but they should not be neglected nevertheless.

Acknowledgements. We are grateful for financial support from the TU Vienna within the Innovative Project "The impact of biological structures on ice nucleation" and from the FWF (P23027). We also thank the OMV for funding the light microscope, the European Union for funding the measurements at the simulation chamber within the Eurochamp2 project and the Hochschuljubiläumsstiftung (Project H-2075/2010) of the city of Vienna for funding the swing mill. We want to thank L. Puchinger for the allocation of the Zeiss Microscope, C. Zetzsch and U. Krüger for support at the simulation chamber. Furthermore we acknowledge J. Frank and R. Rosner for construction of the cryo cell and the overheat safeguard, K. Whitmore for the tutoring at the FEGSEM and K. Kassin for helpful discussions. We thank K. A. Pratt for additional information about her field measurements, and T. Koop for freezing point calculations.

Edited by: U. Pöschl

\section{References}

Ariya, P. A., Sun, J., Eltouny, N. A., Hudson, E. D., Hayes, C. T., and Kos, G.: Physical and chemical characterization of bioaerosols - implications for nucleation processes, Int. Rev. Phys. Chem., 28, 1-32, 2009.

Breslow, R. and Rizzo, C. J.: Chaotropic salt effects in a hydrophobically accelerated Diels-Alder reaction, J. Am. Chem. Soc., 113, 4340-4341, 1991.

Burrows, S. M., Elbert, W., Lawrence, M. G., and Pöschl, U.: Bacteria in the global atmosphere - Part 1: Review and synthesis of literature data for different ecosystems, Atmos. Chem. Phys., 9, 9263-9280, doi:10.5194/acp-9-9263-2009, 2009.

Cheftel, J. C., Lévy, J., and Dumay, E.: Pressure-assisted freezing and thawing: principles and potential applications, Food Rev. Int., 16, 453-483, doi:10.1081/FRI-100102319, 2000.

Clarke, A., Gleeson, P., Harrison, S., and Knox, R. B.: Pollenstigma interactions: identification and characterization of surface components with recognition potential, P. Natl. Acad. Sci., 76, 3358-3362, 1979.

DeMott, P. J. and Prenni, A. J.: New Directions: Need for defining the numbers and sources of biological aerosols acting as ice nuclei, Atmos. Environ., 44, 1944-1945, 2010.

Diehl, K. and Mitra, S. K.: A laboratory study of the effects of a kerosene-burner exhaust on ice nucleation and the evaporation rate of ice crystals, Atmos. Environ., 32, 3145-3151, 1998.

Diehl, K., Quick, C., Matthias-Maser, S., Mitra, S. K., and Jaenicke, R.: The ice nucleation ability of pollen, part I, Atmos. Res., 58, 75-87, 2001.

Diehl, K., Matthias-Maser, S., Jaenicke, R., and Mitra, S. K.: The ice nucleation ability of pollen, part II, Atmos. Res., 61, 125133, 2002.

Dingle, A. N.: Pollens as condensation nuclei, J. Rech. Atmos., 2, 231-237, 1966.

Dubois, M., Gilles, K. A., Hamilton, J. K., Rebers, P. A., and Smith, F.: Colorimetric method for determination of sugars and related substances, Anal. Chem., 28, 350-356, 1956. 
Duman, J. G.: Antifreeze and ice nucleator proteins in terrestrial arthropods, Annu. Rev. Physiol., 63, 327-357, 2001.

Goldstein, G. and Nobel, P. S.: Changes in osmotic pressure and mucilage during low-temperature acclimation of Opuntia ficusindica, Plant Physiol., 97, 954-961, 1991.

Goldstein, G. and Nobel, P. S.: Water relations and low-temperature acclimation for cactus species varying in freeing tolerance, Plant Physiol., 104, 675-681, 1994.

Gross, D. C., Proebsting, E. L., and Maccrindle-Zimmermann, H.: Development, distribution, and characteristics of intrinsic, nonbacterial ice nuclei in Prunus wood, Plant Physiol., 88, 915-922, 1988.

Grote, M.: Techniques to preserve soluble surface components in birch pollen wall: A scanning and transmission electron microscopic study, J. Histochem. Cytochem., 37, 981-987, 1989.

Hoose, C., Kristjanssin, J. E., and Burrows, S. M.: How important is biological ice nucleation on a global scale?, Environ. Res. Lett., 5, 7 pp., doi:10.1088/1748-9326/5/2/024009, 2010.

Howe, G. T., Aitken, S. N., Neale, D. B., Jermstad, K. D., Wheeler, N. C., and Chen, T. H. H.: From genotype to phenotype: unraveling the complexities of cold adaptation in forest trees, Can. J. Bot., 81, 1247-1266, 2003.

Iannone, R., Chernoff, D. I., Pringle, A., Martin, S. T., and Bertram, A. K.: The ice nucleation ability of one of the most abundant types of fungal spores found in the atmosphere, Atmos. Chem. Phys., 11, 1191-1201, doi:10.5194/acp-11-1191-2011, 2011.

Jacobson, M. Z. and Streets, D. G.: Influence of future anthropogenic emissions on climate, natural emissions, and air quality, J. Geophys. Res., 114, D08118, doi:10.1029/2008JD011476, 2009.

Kelly, D.: The evolutionary ecology of mast seeding, Trends Ecol. Evol., 9, 465-470, 1994.

Kieft, T. L. and Ruscetti, T.: Characterization of biological ice nuclei from a lichen, J. Bacteriol., 172, 3519-3523, 1990.

Koop, T. and Zobrist, B.: Parameterization for ice nucleation in biological and atmospheric systems, Phys. Chem. Chem. Phys., 11, 10839-10850, 2009.

Kovacik, L., Plitzko, J. M., Grote, M., and Reichelt, R.: Electron tomography of structures in the wall of hazel pollen grains, J. Struct. Biol., 166, 263-271, 2009.

Lohmann, U.: A glaciation indirect aerosol effect caused by soot aerosols, Geophys. Res. Lett., 29, 1052, doi:10.1029/2001GL014357, 2002.

Marcolli, C., Gedamke, S., Peter, T., and Zobrist, B.: Efficiency of immersion mode ice nucleation on surrogates of mineral dust, Atmos. Chem. Phys., 7, 5081-5091, doi:10.5194/acp-7-50812007, 2007.

Mims, F. M.: Solar corona caused by juniper pollen in Texas, Appl. Optics, 37, 1486-1488, 1998.

Mishcenko, M. I., Rossow, W. B., Macke, A., and Lacis, A. A.: Sensitivity of cirrus cloud albedo, bidirectional reflectance and optical thickness retrieval accuracy to ice particle shape, J. Geophys. Res., 101, 16973-16985, 1996.

Möhler, O., Nink, A., Saathoff, H., Schaefers, S., Schnaiter, M., Schöck, W., and Schurath, U.: The Karlsruhe aerosol facility chamber AIDA: technical description and first result of homogeneous and heterogeneous ice nucleation experiments, Workshop Ion-Aerosol-Cloud Interactions, 2001-007, Geneva, 2001.

Möhler, O., Stetzer, O., Schaefers, S., Linke, C., Schnaiter, M.,
Tiede, R., Saathoff, H., Krämer, M., Mangold, A., Budz, P., Zink, P., Schreiner, J., Mauersberger, K., Haag, W., Kärcher, B., and Schurath, U.: Experimental investigation of homogeneous freezing of sulphuric acid particles in the aerosol chamber AIDA, Atmos. Chem. Phys., 3, 211-223, doi:10.5194/acp-3-211-2003, 2003.

Möhler, O., DeMott, P. J., Vali, G., and Levin, Z.: Microbiology and atmospheric processes: the role of biological particles in cloud physics, Biogeosciences, 4, 1059-1071, doi:10.5194/bg-4-10592007, 2007.

Morris, C. E., Georgakopoulos, D. G., and Sands, D. C.: Ice nucleation active bacteria and their potential role in precipitation, J. Phys. IV France, 121, 87-103, 2004.

Mugnano, J. A., Lee, R. E., and Taylor, R. T.: Fat body cells and calcium phosphate spherules induce ice nucleation in the freezetolerant larvae of the gall fly Eurosta solidaginis, J. Exp. Biol., 199, 465-471, 1996.

Murray, B. J., Broadley, S. L., Wilson, T. W., Bull, S. J., Wills, R. H., Christenson, H. K., and Murray, E. J.: Kinetics of the homogeneous freezing of water, Phys. Chem. Chem. Phys., 12, 10380-10387, 2010.

Murray, B. J., Broadley, S. L., Wilson, T. W., Atkinson, J. D., and Wills, R. H.: Heterogeneous freezing of water droplets containing kaolinite particles, Atmos. Chem. Phys., 11, 4191-4207, doi:10.5194/acp-11-4191-2011, 2011.

Niedermeier, D., Shaw, R. A., Hartmann, S., Wex, H., Clauss, T., Voigtländer, J., and Stratmann, F.: Heterogeneous ice nucleation: exploring the transition from stochastic to singular freezing behavior, Atmos. Chem. Phys., 11, 8767-8775, doi:10.5194/acp11-8767-2011, 2011.

Pope, F. D.: Pollen grains are efficient cloud condensation nuclei, Environ. Res. Lett., 5, 044015, doi:10.1088/17489326/5/4/044015, 2010.

Pouleur, S., Richard, C., Martin, J. G., and Antoun, H.: Ice nucleation activity in Fusarium acuminatum and Fusarium avenaceum, Appl. Environ. Microbiol., 58, 2960-2964, 1992.

Pratt, K. A., DeMott, P. J., French, J. R., Wang, Z., Westphal, D. L., Heymsfield, A. J., Twohy, C. H., Prenni, A. J., and Praether, K. A.: In situ detection of biological particles in cloud ice-crystals, Nat. Geosci., 2, 398-401, 2009.

Prenni, A. J., Petters, M. D., Kreidenweis, S. M., Heald, C. L., Martin, S. T., Artaxo, P., Garland, R. M., Wollny, A. G., and Pöschl, U.: Relative roles of biogenic emissions and Saharan dust as ice nuclei in the Amazon basin, Nat. Geosci., 2, 402-405, 2009.

Pummer, B. G., Bauer, H., Bernardi, J., Bleicher, S., and Grothe, H.: Birch and conifer pollen are efficient atmospheric ice nuclei, Atmos. Chem. Phys. Discuss., 11, 27219-27241, doi:10.5194/acpd-11-27219-2011, 2011.

Schäppi, G. F., Taylor, P. E., Pain, M. C. F., Cameron, P. A., Dent, A. W., Staff, I. A., and Suphioglu, C.: Concentrations of major grass group 4 allergens in pollen grains and atmospheric particles: implications for hay fever and allergic asthma sufferers sensitized to grass pollen allergens, Clin. Exp. Allergy, 29, 633-641, 1999.

Schnell, R. C. and Vali, G.: Atmospheric ice nuclei from decomposing vegetation, Nature, 236, 163-165, 1972.

Solomon, W. R., Burge, H. A., and Muilenberg, M. L.: Allergen carriage by atmospheric aerosol: Ragweed pollen determinants in smaller micronic fractions, J. Allergy Clin. Immunol., 72, 443-447, 1983. 
Swoboda, I., Grote, M., Verdino, P., Keller, W., Singh, M., B., DeWeerd, N., Sperr, W. R., Valent, P., Balic, N., Reichelt, R., Suck, R., Fiebig, H., Valenta, R., and Spitzauer, S.: Molecular characterization of polyglacturonases as grass pollen specific marker allergens: expulsion from pollen via submicronic respirable particles, J. Immunol., 172, 6490-6500, 2004.

Tsumuki, H. and Konno, H.: Ice nuclei produced by Fusarium sp. Isolated from the gut of the rice stem borer Chilo suppressalis WALKER, Biosci. Biotech. Biochem., 58, 578-579, 1994.

Vali, G., Christensen, M., Fresh, R. W., Galyan, E. L., Maki, R., and Schnell, R. C.: Biogenic ice nuclei part II: bacterial sources, J. Atmos. Sci., 33, 1565-1570, 1976.

von Blohn, N., Mitra, S. K., Diehl, K., and Borrmann, S.: The ice nucleation ability of pollen, part III, Atmos. Res., 78, 182-189, 2005.

Wolber, P. K., Deininger, C. A., Southworth, M. W., Vandekerckove, J., van Montagu, M., and Warren, G. J.: Identification and purification of a bacterial ice-nucleation protein, P. Natl. Acad. Sci. USA, 83, 7256-7260, 1986.
Yttri, K. E., Dye, C., and Kiss, G.: Ambient aerosol concentrations of sugars and sugar-alcohols at four different sites in Norway, Atmos. Chem. Phys., 7, 4267-4279, doi:10.5194/acp-7-4267-2007, 2007.

Zachariassen, K. E. and Kristiansen, E.: Ice nucleation and antinucleation in nature, Cryobiology, 41, 257-259, doi:10.1006/cryo.2000.2289, 2000.

Zimmermann, F., Weinbruch, S., Schütz, L., Hofmann, H., Ebert, M., Kandler, K., and Worringen, A.: Ice nucleation properties of the most abundant mineral dust phases, J. Geophys. Res., 113, D23204, doi:10.1029/2008JD010655, 2008.

Zobrist, B., Marcolli, C., Peter, T., and Koop, T.: Heterogeneous ice nucleation in aqueous solutions: the role of water activity, $\mathrm{J}$. Phys. Chem. A, 112, 3965-3975, 2008. 